\title{
Comparative Effectiveness of Context-based and Traditional Approaches in Teaching Genetics: Student Views and Achievement
}

\author{
Monde Kazeni and Gilbert Onwu* \\ University of Pretoria, South Africa \\ ${ }^{*}$ Corresponding author, email: gilbert.onwu@yahoo.com
}

The study aimed to determine the comparative effectiveness of context-based and traditional teaching approaches in enhancing student achievement in genetics, problem-solving, science inquiry and decision-making skills, and attitude towards the study of life sciences. A mixed method but essentially quantitative research approach involving a quasi-experimental, non-equivalent pre-test post-test control group design was used for the investigation. A total of 190 students from six grade 11 intact science classes, and their six teachers drawn from the six high schools in Tshwane South educational district in Gauteng, South Africa comprised the study sample. The participating teachers taught a genetics course made up of several themes to students in the control and experimental groups over a 7-week period. Five instruments were used to assess student performance in genetics content knowledge, science inquiry skills, problem-solving and decision-making abilities and attitude towards life sciences. Qualitative data derived from teachers' and students' interview protocols were used to supplement the quantitative data. The results suggest that context-based teaching was significantly better than traditional teaching approaches in enhancing student performance, apart from specific science inquiry skills. Performance differences were strongly associated with the type of contexts used in designing the genetics learning materials, and the context-based teaching model used for implementing the materials.

Keywords: context-based teaching; problem solving skills; inquiry skills; decision making skills; attitudes; genetics

\section{Introduction}

Although science still remains one of the most important subjects in South Africa's school curriculum, science as a subject of choice has repeatedly failed to excite and attract students to engage with the discipline (Centre for Development and Enterprise (CDE), 2010). The reasons for this state of affairs are diverse and complex. First, science is frequently taught in South African schools as rote memorization of complex facts and abstract or meaningless data (Reddy, 2006), which in a sense is antithetical to the visceral driven way we live and interact with our environment (Onwu \& Stoffels, 2005). Second, science teachers have failed in their social responsibility to provide students and indeed the public with an understanding of the personal rewards of science, including science's potentially beneficial effect on personal development (Onwu \& Kyle, 2011; Sadler, 2009). Thirdly, failure of science teachers to develop valid teaching approaches that seek to link students' day-to-day lived experiences to their science classroom experiences (cf. Dube \& Lubben, 2011) is likely to further obscure and diminish the relevance of science education in their lives.

In the attempt to increase student motivation and make the teaching of science concepts more relevant and interesting, there has been a discernible international trend in science education 
towards the use of context-based teaching approaches (Bennett \& Holman, 2002; Gilbert, Bulte, \& Pilot, 2011). According to Gilbert et al. (2011), the initial philosophy underpinning context-based science education was to involve both the contexts in which concepts were used and the relations between those concepts in a more coherent and explicit way. The idea was to make content knowledge more accessible by incorporating scenarios of daily life experiences of students, and applications of science into science learning activities in structured ways that help to demonstrate the relationship between the concepts and the context, however defined (Bennett \& Holman, 2002; Dube \& Lubben, 2011; Gilbert et al., 2011). Recently, there have also been moves to use context-based education to change the emphasis in science education from its strongly conceptual tone of learning scientific 'facts', to engaging students more in scientific reasoning activities such as critical discussion, argumentation, and experimental designing (Krajcik, McNeill, \& Reiser, 2008).

The term context is a complex construct and has had as many definitions as there are practitioners in the field. In science education, 'contexts' have been variously defined in terms of environmental, societal, health, personal, community, economic, technological and industrial applications that could be used in developing science curriculum materials (Bennett, 2003). The Queensland Studies Authority (2004, p. 11) has defined 'context' as, 'a group of learning experiences that encourage students to transfer their understanding of key concepts to situations that mirror real life'. Taylor and Mulhall (1997) further describe learning in context as the case when the content of the curriculum and methods and materials associated with it are related directly to the experiences and environment of the students. This view of contextualized teaching and learning is in consonant with Baker, O'Neil, and Linn (1994)'s description of contexts, which signals authentic tasks that are meaningful to the student. Thus contexts have been alternately described as a theme, situation, issue, story, practice, application, experience or a problem (Bulte, Westbroek, De Jong, \& Pilot, 2006; Whitelegg \& Parry, 1999).

Two ideas, however, which are common to the various definitions of context seem to emerge, namely; the situated-ness of learning and the linkage of teaching to students' real-life experiences. In this study, context-based teaching in science is simply defined as science teaching that attempts to develop science concepts and skills from situations of daily life experiences with which students themselves are familiar and perceive as relevant. The definition is not unconnected with the views of other researchers (Bennett \& Holman, 2002; Roth \& Lee, 2004; Sadler, 2009) who maintain that science education should foster science classroom settings that promote self and social empowerment for meaningful learning, in which students and teachers actively engage in exploring socio-scientific issues that are of relevance to them.

The question that we sought to address, was whether context-based science teaching would be more efficacious than traditional teaching approaches, defined here as the usual ways of teaching science, in (a) enhancing achievement in genetics, a topic considered difficult to learn (Dairianathan \& Subramaniam, 2011; Furberg \& Arnseth, 2009; Knight \& Smith, 2010), and (b) in facilitating the development of higher-order thinking skills of problem-solving, decision-making, and science inquiry skills, as well as (c) in improving students' attitude towards the study of life sciences.

Genetics, a life science topic, was selected for study for several reasons. First, life sciences generally, are becoming increasingly important for understanding and addressing socio-scientific issues such as, hunger and malnutrition, environmental degradation, access to clean water and sanitation, which often frame transformation concerns for sustainable development of many African governments including South Africa. Second, life sciences have generally been assumed to be 'softer' science, compared with physical sciences. But, in the South African setting, students' performance in life sciences has been as poor if not worse than that in physical sciences (Department of Education [DoE], 2009). Thirdly, chief examiners' reports have noted that several life sciences topics, notably genetics, present a veritable challenge to both students and teachers. Indeed, various studies (Dogru-Atay \& Tekkaya, 2008; Ibanez-Orcajo \& Martinez-Aznar, 2005; Lewis \& Kattman, 2004) have shown that students' difficulties with this topic are related to the lack of conceptual understanding of genetics concepts, confusion in the use of domain-specific vocabulary and terminology in genetics, very limited understanding of the nature of genetics-related problems requiring application and reasoning skills, and perceived irrelevance of genetics to students' daily lives. 
Given that South Africa's new life sciences curriculum recommends the use of every-day life experiences in teaching the subject, what was of particular interest to us was whether a contextbased teaching approach would be more facilitative than the traditional teaching approaches in improving student achievement in genetics, since several researchers (Mji \& Makgato, 2006; Wilke, 2003) have associated the difficulty in learning certain science topics with ineffective instructional methods.

A systematic review by Bennett, Lubben, and Hogarth (2007) of the effects of context-based and Science-Technology-Society (STS) teaching approaches showed positive motivational effects but inconsistency in the results with regard to student conceptual achievement. Other factors of course, could account for the inconsistent results, not the least the type of contexts (De Jong, 2008; Gilbert, 2006) or the teaching model used to implement the curriculum materials. This study is an attempt to give further substance to the debate.

\section{Theory}

\section{Context-based approach used in implementing the study materials}

The complexity of understanding how the lack of relevance has impacted on students' science learning, in this case of genetics, is illustrated by the context-based frameworks within which the study was conceived. The study was grounded partly, in theoretical discourse, and partly in empiricism. Gilbert et al. (2011) identified four context-based approaches to the teaching of school science materials. The first focuses on specific science concept learning in which applications of the science concept, as context, are addressed perhaps as an afterthought, at the end of the lesson. The second links scientific concepts to their applications, in ways that those applications of necessity give meanings to the concepts. The third emphasizes the use of science-related situations 'woven' into stories or narratives that could be construed as 'contexts' for teaching the concept. And the fourth approach stresses context as social circumstances in which the concepts to be taught are relatable to socio-scientific issues say, that affect the community. In line with our research interest, as described later, we adopted the approach in which science-related situations woven into narratives as contexts, precede the introduction of the concepts to be taught.

\section{Determination of contexts for development of genetics teaching materials}

There are a variety of ways in which 'context' has been alternately defined and usefully applied in science education. Indeed, earlier literature did suggest that students' interest and participation in science lessons are enhanced to a large extent by lessons or 'contexts' which have personal, and useful applications of science (Campbell, Lubben, \& Dlamini, 2000). In more recent times, Wieringa, Janssen, and Van Driel (2011) claim that the term most frequently used to denote context is context as a 'situation'. For instance, some studies have chosen 'context types' based on only those situations that are perceived to correlate strongly with students' personal circumstances (Anderson, 2006; Schreiner \& Sjøberg, 2004; Taasoobshirazi \& Carr, 2008), or have societal/community relevance (Sadler, 2009). For others, the selection of contexts has included all situations that may have relevance to students' future career prospects or scientific and technological innovations (Aikenhead, 2007). What can be gleaned from a majority of those studies is that the type of situation selected to define context varies. And recent research now seems to suggest that the nature of context used and the order in which it is presented in relation to the concept to be learned is likely to be important for the success of context-based education (De Jong, 2008). Interestingly enough, curriculum developers of context-based science education have almost consistently and exclusively used contexts, which they themselves as adults and experts (not the students) think are relevant to students, as the sole criterion for the selection of contexts (Bennett \& Holman, 2002). And the results have not always been as anticipated. It was precisely for this reason among others, that we thought it necessary for the students themselves to identify types of contexts or situations, which they themselves felt would likely help to make the learning of genetics concepts more meaningful, relevant and accessible to them. 


\section{The Study}

The main questions addressed in the study are:

1. Would there be any significant differences in performance between students exposed to a context-based teaching and those exposed to traditional teaching approaches with respect to:

i. Achievement in genetics?

ii. Enhancement of science inquiry skills?

iii. Enhancement of problem-solving ability?

iv. Enhancement of decision-making ability?

v. Improvement of student attitude towards the study of life sciences?

2. What are students' and teachers' views on features of the context-based and traditional teaching approaches that could account for differences, if any, in student performance on the assessed learning outcomes?

Five null hypotheses were derived from the first research question and tested, namely, that there will be no significant differences between the performances of the experimental and control group classes in each of the five listed learning outcomes.

The second research question was explored using student and teacher interview protocols.

\section{Conceptual framework}

The study's conceptual framework was based on Hung's (2006) 3C3R [Content, Context, Connections (3C) and Researching, Reasoning, Reflecting (3R)] model for designing Problem-Based learning. The elements of the $3 \mathrm{C} 3 \mathrm{R}$ model consist of a core component, comprising the $3 \mathrm{Cs}$, and a process component involving the 3Rs. Hung's model was considered appropriate for providing a useful framework because the model through its constituent elements emphasizes as an integrated whole, those areas that are of interest to us in the study, notably contextualised teaching, conceptual/content learning, use of higher-order thinking skills of investigating, analytical reasoning, problem-solving, reflecting and decision-making.

Thus, the core component comprised the genetics content knowledge taught, the contexts used in teaching the content material, and the connections or linkages made between the content and contexts. This component may be considered as underpinned by a situated learning framework (Brown, Collins, \& Duguid, 1989). The process component was about the teaching and learning activities', mostly done through critical discussions, arguments, debates, practical investigations and is seen as forming part of the cultural dialectics of the science classroom in the tradition of social constructivism (O'Loughlin, 1992; Solomon, 1987).

Additionally, in order to address the concern of some authors (e.g. Gilbert, 2006) that practitioners generally do not implement context-based innovations in a systematic and organised way another component, the learning cycle, was introduced as an important aspect of the study's conceptual framework. The learning cycle provided a framework for organizing in a systematic way the order of presentation of contexts in relation to the concepts to be taught. Learning cycles as envisaged are controlled instructional methods for introducing students to inquiry-based learning experiences, which are similar to context-based teaching approaches (De Jong, 2008; Dogru-Atay \& Tekkaya, 2008). For this study, a 5-phase learning cycle model was used, and is described later. Other workers (Dogru-Atay \& Tekkaya, 2008; Wieringa et al., 2011) have also used modified versions of the learning cycle model in contextbased education.

\section{Methodology}

\section{Research design}

We adopted a mixed method but essentially quantitative research approach involving a non-equivalent pre-test-post-test control group quasi-experimental design (Campbell \& Stanley, 1966), to compare the performances of students in intact classes who had been exposed to context-based and traditional 
teaching approaches respectively. Qualitative data from interviews with participating teachers and focus groups of students were used to provide more insight into the plausible interpretations of the results.

\section{Sampling procedure and sample}

A systematic stratified sampling procedure (Babbie, 2011) was used to select six government schools from the population of schools in the Tshwane South educational district of Pretoria, in South Africa. The district has a wide spectrum of the so-called township (peri-urban) schools made up of high, average and low performing schools in terms of School Leaving Certificate examination results. Students from under-resourced township schools were the target participants as they form a large percentage of the Tshwane South schools, and as such, they probably contribute a larger share of the poor life science results in recent years. The majority of the students in the schools come from low to medium socio-economic status groups.

Grade 11 separate intact classes from three schools, comprising in total 87 students (55 girls 32 boys), constituted the experimental group. Grade 11 intact classes from three other schools, consisting of a total of 103 students ( 54 girls and 49 boys), made up the control group. Six participating teachers, three each from experimental and control groups, and 58 students ( 25 from control group and 33 from experimental group) formed the sample for the individual teacher interviews and students' focus group sessions (5-6 members per group), respectively. All the six teachers were qualified to teach life sciences with academic qualifications ranging from bachelor's degree (BEd) to honours degree (BEd Hon.). All six had a minimum of 8 years of life sciences teaching experience. None of the participating teachers have had any professional development activities aimed at designing or implementing context-based science education prior to the study.

\section{Design of context-based teaching materials}

The contexts used in the development of genetics materials were determined from a survey of grade 12 secondary school students who had just completed the study of genetics. Based on their experiences, they selected contexts, which they felt could make the study of genetics more relevant, accessible and interesting to them. The students mostly preferred situations related to their personal lives (e.g. health issues, formation of characteristic traits), those related to societal issues (e.g. transmission of genetic diseases), followed by contexts related to science and technology practices and innovations (cloning of animals) and environmental issues (e.g. extinction of species).

Those contexts generated by the students together with content from the life sciences curriculum, were used to design the context-based genetics lesson materials. The written contexts in form of narratives were used to introduce each lesson (cf. Bennett et al., 2007). Interested readers may contact the authors for access to the lesson materials.

\section{Training of participating teachers}

Before the intervention, 11 teachers who volunteered to teach the experimental group were exposed to the principles underpinning context-based instructional approach and trained on how to implement a manual for teaching a course on genetics using the approach. The manual contained context-based teaching materials and accompanying students' learning activities. The training took 2 days and emphasized design principles in planning and implementing the 5-phases of the lesson cycle model. Following the training, each of the teachers was required to prepare a context-based genetics lesson for presentation to a panel of judges comprising three experienced university science education lecturers (who had participated in the workshops) and the two researchers. Teachers were not required to design large lesson modules or sophisticated learning materials. Our interest was in observing how they followed the context-based approach and the design principles in planning and presenting their lessons. In designing the lessons it was expected that teacher's personal practical knowledge (Wieringa et al., 2011) would play an important role. The panel assessed each teachers' readiness according to a specific set of criteria. Based on the ratings of the judges three teachers from different schools were selected for the experimental group. The control group teachers were neither trained nor given a 
teaching manual. They were however, each given a list of the genetics themes and concepts to be taught (same as those for the experimental group) and were expected to use their personal practical knowledge (day-to-day lesson planning/design of activities) to present the topics as they would normally do.

\section{Implementation of the context-based lesson materials}

The five-phase learning cycle was used to present the lessons which started with narratives of authentic situations as follows:

(1) Introduction of contexts

(2) Interrogation of the contexts

(3) Introduction of content

(4) Linkage of content and contexts

(5) Assessment of learning

The example below of a context-based lesson on the determination of sex of children in a family is used to illustrate the implementation of the five-phase learning cycle.

\section{Phase 1: Introduction of contexts}

The following narrative is designed to arouse interest and to stimulate focused student thinking about a familiar genetic-related situation.

\section{Narrative:}

Mr. and Mrs. Sizwe have been married for twelve years. They have four daughters, and no son. According to Mr. Sizwe's custom, not to have a son means that there would be no heir to succeed him. Mr. Sizwe decided to consult his elders about his situation. After consulting with them, he decided to take on a second wife who would bear him a son. To his dismay, the second wife gave birth to a girl.

The question is: How can the situation about sex determination be resolved scientifically?

\section{Phase 2: Interrogation of context}

In phase two, students worked in small groups of four to five to try to answer the following questions:

(1) Who is responsible for determining the sex of a child (the husband or wife)?

(2) How is the sex of a child determined?

(3) Why do some couples have girls or boys only?

(4) Does it matter to you whether you have boys or girls only or both?

This phase allowed students to discuss the situation in order to identify what preconceptions they have, what they already know about it or do not know, and to attempt to reason around and resolve emerging issues of a personal or societal nature.

\section{Phase 3: Introduction of content (concepts)}

The third phase involved the presentation of relevant genetics content knowledge by the teacher. Only content that was necessary to explain, clarify, or solve the introduced context was taught (ref. Table 1). Concepts and ideas were actively linked to the context at opportune times, and if need be, concepts were re-visited again and again, in the different themes of the topic. A variety of structured student learning activities was used to introduce concepts, including guided discussions, knowledge exposition, role play, practical activity, and modelling.

\section{Phase 4: Linkage of content and context}

In the fourth phase, students worked in small groups (four to five students) to re-visit the issues raised and the explanations given in phase 2. They discussed the following questions:

Having studied how the sex of a child is determined: 
Table 1: An example of the theme, narrative and relevant genetics content of a lesson

\begin{tabular}{|c|c|c|}
\hline Theme & Narrative & Relevant genetics content \\
\hline Sex determination & $\begin{array}{l}\text { A family situation as } \\
\text { to how the sex of } \\
\text { a baby is determined }\end{array}$ & $\begin{array}{l}\text { Gamete formation-Meiosis; genetic composition } \\
\text { of the egg and sperm. } \\
\text { Inheritance-Fertilization, homologous } \\
\text { chromosomes, DNA replication and } \\
\text { mitosis (growth), Mendel's experiments } \\
\text { Monohybrid inheritance-Genotypes and } \\
\text { phenotypes, alleles, dominant and recessive alleles, } \\
\text { Proportions and predictions-Genetic } \\
\text { crosses and punnett squares, test cross. }\end{array}$ \\
\hline
\end{tabular}

1. Do you still maintain the explanations and answers you gave earlier in phase 2?

(a) If your answer is yes, explain why you think your original answers and explanations are correct?

(b) If your answer is no, why have you decided to change your original answers and explanations?

2. Can you think of any questions that cannot be answered using the information you know?

The aim was for students to make the necessary connections between the content taught and the context under study. In essence, for them to think 'genetically' and build up coherent conceptual frameworks.

\section{Phase 5: Assessment of learning}

In the final assessment of learning phase, students were given tasks requiring the application of the concepts learnt to novel situations as follows:

(1) Explain why some twins have the same sex, while other twins may have different sexes.

(2) Your friend tells you that it is possible for a couple to decide whether to have a girl or a boy. Do you agree? What would you tell your friend? Explain

(3) If you were to find yourself in the same position as Mr Sizwe what would you decide to do?

(4) A child is born with both male and female reproductive organs. What could have caused this anomaly?

In answering these assessment questions, students were envisioned as (i) generally building up coherent conceptual frameworks and (ii) beginning to realize that their existing knowledge of necessity frames the way they may view personal and societal issues.

\section{Data collection}

Consenting grade 11 students from intact experimental and control classes were pre- and post tested respectively on six research instruments used to collect data. The five instruments' Pearson correlation coefficient reliabilities ( $r$ ) were determined in a pilot study using the test-retest reliability method (Gall, Gall, \& Borg, 2007). All instruments were face and content validated by experts in the field, namelythree life sciences university lecturers and three science education university lecturers. The instruments were adapted from previous researches and they comprised (i) a life-sciences attitude questionnaire [LSAQ; $r=0.93$ ] (Ferreira, 2004; Jenkins \& Nelson, 2005; Schreiner \& Sjøberg, 2004); (ii) decision-making ability test [DMAT; $r=0.95$ ] (Maloney, 2007); (iii) problem-solving ability test [PSAT; $r=0.82$ ] (Organization for Economic Co-operation and Development - OECD, 2004); (iv) test of integrated science inquiry skills [TOSIS; $r=0.83$ ] (Dillashaw \& Okey, 1979); and (v) genetics content knowledge test [GCKT $-r=0.88$ ] adapted from past South African senior certificate life sciences examination papers. The five instruments were administered in that order. 
Both the experimental and control group teachers taught their normal class groups for a period of 7 weeks. Sample lessons of both groups were intermittently observed to assure consistency. Following the administration of the post tests, interviews were later held with the teachers to get their views about students' performance and the reasons for the performance differences, if any. Focus group discussions were used to elicit students' views as well.

\section{Results of the Study}

\section{Quantitative data}

Table 2 summarizes the pre-test and post-test descriptive and inferential statistics results of the assessed learning outcomes of both the experimental $(E)$ and control $(C)$ groups. The analysis of variance results of pre-test mean scores showed no significant differences between the performance of the control and experimental groups on all the learning outcomes assessed (Table 2).

Lack of significant differences between the pre-test performances of the two groups would infer that the cognate abilities of the groups were approximately the same prior to the intervention. Following the intervention, the analysis of covariance of post-test mean scores showed significant differences between the performances of the two groups in favor of the experimental group as shown in Table 2. Four of the five null hypotheses were rejected.

The results show that the experimental group performed significantly better than the control group in genetics content knowledge $(F=63.00 ; p<0.0001)$; decision-making ability $(F=17.22 ; p<0.0001)$; problem-solving ability $(F=16.57 ; p<0.0001)$; and more positive attitude towards the study of life sciences $(F=25.04 ; p<0.0001)$. Results from the test of science inquiry skills showed no significant difference between the overall performances of the two groups (Table 2). However, with the individual integrated inquiry skills of their ability to formulate hypotheses (HYPO: $F[1,163]=33.21, p<0.0000$ ), and to draw conclusions from results (CONC: $F[1,163]=7.70, p=0.0062)$, there were significant differences in performance between the experimental and control groups in favour of the experimental group. It is pertinent to note that those two inquiry skills were especially in demand in the learning cycle model used, and the results would suggest that their consistent use in the classrooms could have resulted in the transfer of skills (learned skill), hence the improved performance. However, there were no significant differences between the two groups in their ability to identify variables, design experiments and graphing. Further statistical analysis also showed no significant interactive influence of gender and treatment on the performance of students. Both boys and girls were not differently affected statistically.

In sum, the use of context-based teaching approach was significantly more efficacious than the traditional teaching in enhancing student's performance in all the learning outcomes assessed, except for the overall science inquiry skills.

\section{Qualitative data}

Post intervention focus group interviews held with both the experimental and control group student members revealed that first, students from the experimental group found the study of genetics enjoyable and great fun and expressed confidence about their post-test performance in genetics. Secondly, they mostly attributed their performance to the way the genetics topic was taught as evident in the following interview excerpts.

Student E1: 'If all educators taught us the way sir (the teacher) did, we would never fail any subject. I enjoyed looking back at my original ideas'. (Reference to stages 2 and 4 of the learning cycle)

Student E2: 'The nice thing about the lessons was that we talked about things that happen in our own homes. I now understand why my brother looks so different from all of us'. (Familiar and relevant context)

Student E3: 'The stories made the study of genetics easy because we managed to understand what was happening and were able to explain the situations'. (Use of authentic narrative contexts) 
Table 2: Summary of pre-test and post-test descriptive and inferential statistics of the assessed learning outcomes (LSAS, GCKT, TOSIS, DMAT, PSAT)

\begin{tabular}{|c|c|c|c|c|c|c|c|c|c|c|c|}
\hline \multirow[b]{2}{*}{ Test } & \multirow[b]{2}{*}{ Treatment } & \multicolumn{5}{|c|}{ Pre-test statistics } & \multicolumn{5}{|c|}{ Post-test statistics } \\
\hline & & $N$ & Mean $(\bar{x})$ & $S D$ & $F$-value & $p$-value & $N$ & Mean $(\bar{x})$ & $S D$ & $F$-value & $p$-value \\
\hline \multirow[t]{3}{*}{ GCKT } & $E$ & 87 & 10.21 & 5.15 & 0.03 & 0.8610 & 85 & 26.68 & 11.14 & 63.00 & $<0.0001^{*}$ \\
\hline & C & 101 & 10.35 & 5.31 & & & 93 & 15.46 & 7.60 & & \\
\hline & Difference & & -0.14 & & & & & 11.22 & 3.54 & & \\
\hline \multirow[t]{3}{*}{ TOSIS } & E & 86 & 23.95 & 11.61 & 0.12 & 0.7296 & 80 & 28.92 & 10.74 & 3.44 & 0.0654 \\
\hline & C & 99 & 23.38 & 10.75 & & & 86 & 25.41 & 13.61 & & \\
\hline & Difference & & 0.57 & & & & & 3.51 & -2.87 & & \\
\hline \multirow[t]{3}{*}{ DMAT } & $E$ & 87 & 58.32 & 23.62 & 3.19 & 0.0759 & 85 & 68.3 & 18.85 & 17.22 & $<0.0001^{*}$ \\
\hline & C & 94 & 52.23 & 22.25 & & & 86 & 54.7 & 24.79 & & \\
\hline & Difference & & 6.09 & & & & & 13.6 & -5.94 & & \\
\hline \multirow[t]{3}{*}{ PSAT } & $E$ & 88 & 29.69 & 21.31 & 0.09 & 0.7629 & 86 & 48 & 25.80 & 16.57 & $<0.0001^{*}$ \\
\hline & $\mathrm{C}$ & 96 & 30.63 & 20.51 & & & 88 & 34.06 & 19.53 & & \\
\hline & Difference & & -0.94 & & & & & 13.94 & 6.27 & & \\
\hline \multirow[t]{3}{*}{ LSAQ } & $E$ & 86 & 121.66 & 10.78 & 0.21 & 0.6504 & 77 & 127.96 & 9.98 & 25.04 & $<0.0001^{*}$ \\
\hline & C & 99 & 122.37 & 10.49 & & & 82 & 117.16 & 17.73 & & \\
\hline & Difference & & -0.71 & & & & & 10.8 & -7.75 & & \\
\hline
\end{tabular}

KEY: * Indicates a significant treatment effect at á=5\% significance level.

GCKT: Genetics Content Knowledge Test TOSIS: Test of Science Inquiry Skills

DMAT: Decision-Making Ability Test SD: Standard deviation

PSAT: Problem-Solving Ability Test E: Experimental group

LSAQ: Life Sciences Attitude Questionnaire C: Control group 
Student E4: 'It was fun to learn genetics by using our own experiences. It makes genetics so easy. I am sure I have passed the test'. (linking content to context-stage 4)

Teachers who taught the experimental group expressed similar sentiments as their students':

Teacher $A_{E}$ : 'Students were very excited during lessons, especially during phase 4. Sometimes, it was difficult to control them, because they came up with so many questions and suggestions'.

Teacher $\mathrm{B}_{\mathrm{E}}$ : 'For the first time, I did not have to force my students to talk. In fact, I had to control them most of the time. Everyone wanted to say something'.

Teacher $\mathrm{C}_{\mathrm{E}}$ : 'Students who were taught using the new method really understood the lessons, because of relating everything they did to what happens in real life, and the practical activities. Once you give them what happens in real life, and then teach them the relevant genetics concepts, it becomes easier for them to understand'.

Students from the control group also found the study of genetics to be interesting. However, their comments indicated that they were apprehensive about their post-test performance. The reasons for their lack of confidence included difficulty in remembering the many genetics terminology and concepts, and their inability to relate some of the materials meaningfully to their daily life experiences. They had this to say:

Student C1: Educators should always relate what we learn to real life issues, and give more examples of how the things we learn can be applied in life'.

Student C2: 'I think that, if we can do practical activities in genetics, it will be easy to see and understand what is going on in genetics'.

Student C3: 'Genetics is difficult because it is just rules and terms which are difficult to understand'.

Teachers who taught the control group generally confirmed their students' interest in genetics, but acknowledged that their performance was poor, as indicated below:

Teacher $\mathrm{D}_{\mathrm{C}}$ : 'Students appear to be interested in the study of genetics, but they perform poorly in assessments'.

Teacher $\mathrm{E}_{\mathrm{C}}$ : 'Students are usually curious during lessons, they are inquisitive, and have some interest in the lessons, but then they do not seem to understand the concepts'.

Teacher $\mathrm{F}_{\mathrm{C}}$ : 'Students like genetics, because they become excited when we discuss issues in genetics, but they are too lazy to study, that's why they fail'.

It is instructive that the teachers solely attributed the source of student's relatively poor performance to students' behaviour, difficulty in comprehension and poor motivation.

\section{Conclusion}

In concluding, the results show that the context-based teaching approach used in this study was more efficacious than the traditional teaching approaches in improving student performance in genetics, higher-order thinking skills of problem solving and decision-making, and attitude towards life sciences. The results have obvious implications for teachers who wish to foster science classroom settings that promote and engage students more in scientific reasoning activities and decision making. It is hoped that the context-based education model used would provide interested science teachers with a prototype from which curriculum materials could be developed. While we acknowledge the possibility of the Hawthorn effect as one of so-called 'effects of expectation' on the superior performance of the experimental group, the corroborating positive interpretations of the students and teachers seem to indicate that the positive outcomes of the intervention and its effects are likely to be long lasting. 
The elements of the context-based approach which might have contributed to the enhancement of student performance could include:

- The student generated contexts for developing the genetics lesson materials, which might have contributed to increased interest and positive attitude.

- The use of a five-phase learning cycle could have helped to:

- Stimulate and focus students' thinking, and facilitate teachers' identification of students' prior knowledge for possible remediation.

- Enhance students' self-reflection, creativity, and initiative as well as problem-solving and decision-making skills.

- Demonstrate the relationships among concepts and between concepts and contexts that could arise from familiar daily life situations.

Although teachers from the experimental group highly appreciated the context-based teaching approach, the demands it could make on teachers (time factor, syllabus coverage) were identified as possible constraints that could impact on its normal use in South African schools. But, it was also pointed out that the ultimate educational benefit to students and teachers alike, are likely to offset any considerations of time and mental effort required in implementing the approach.

\section{References}

Aikenhead, G. S. (2007). Humanistic perspectives in the science curriculum. In S. K. Abell \& N. G. Lederman (Eds.), Handbook of research on science education (pp. 881-911). Mahwah, NJ: Lawrence Erlbaum.

Anderson, I. K. (2006). The relevance of science education as seen by pupils in Ghanaian junior secondary schools. Unpublished PhD thesis, University of the Western Cape, South Africa.

Babbie, E. (2010). The practice of social research. Florence, KY: Wadsworth.

Baker, E., O'Neil, H. F., Jr., \& Linn, R. L. (1994). Policy and validity prospects for performance-based assessment. Journal for the Education of the Gifted, 17(4), 332-353.

Bennett, J. (2003). Teaching and learning science: A guide to recent research and its application. London: Continuum.

Bennett, J., \& Holman, J. (2002). Context-based approaches to the teaching of Chemistry: What are they and what are their effects? In J. K. Gilbert, O. De Jong, R. Justi, D. Treagust, \& J. H. Van Driel (Eds.), Chemical education: Towards research-based practice (pp. 165-184). Dordrecht, he Netherlands: Kluwer.

Bennett, J., Lubben, F., \& Hogarth, S. (2007). Bringing science to life: A synthesis of the research evidence on the effects of context-based and STS approaches to science teaching. Science Education, 91, 347-370.

Brown, J. S., Collins, A., \& Duguid, P. (1989). Situated cognition and the culture of learning. Educational Researcher, 18(1), 32-42.

Bulte, A., Westbroek, H., De Jong, O., \& Pilot, A. (2006). A research approach to designing chemistry education using authentic practices as contexts. International Journal of Science Education, 28, 1063-1086.

Campbell, B., Lubben, F., \& Dlamini, Z. (2000). Learning science through contexts: Helping pupils make sense of everyday situations. International Journal of Science Education, 22, 239-252.

Campbell, D. T., \& Stanley, J. C. (1966). Experimental and quasi-experimental designs for research: A handbook for research on interactions. Boston, MA: Houghton Mifflin.

Centre for Development and Enterprise [CDE]. (2010, September). The maths and science performance of South Africa's public schools: Some lessons from the past decade. CDE Research no. 1. Johannesburg, South Africa: CDE.

Dairianathan, A., \& Subramaniam, R. (2011). Learning about inheritance in an out-of-school setting. International Journal of Science Education, 33, 1079-1108.

De Jong, O. (2008). Context-based chemical education: How to improve it?. Chemical Education International, 8(1), 1-7. Retrieved May 5, 2010, from http://old.iupac.org/publications/cei/vol8/index.html

Department of Education [DoE]. (2009). Education statistics in South Africa at a glance. Pretoria: Government Printers. Retrieved March 20, 2009, from www.education.gov.za

Dillashaw, F. G., \& Okey, J. R. (1979). Test of Integrated Process Skills (TIPS). Athens, Georgia: The University of Georgia.

Dogru-Atay, P., \& Tekkaya, C. (2008). Promoting students' learning in genetics with the learning cycle. The Journal 
of Experimental Education, 76(3), 259-280.

Dube, T., \& Lubben, F. (2011). Swazi teachers' views on the use of cultural knowledge for integrating education for sustainable development into science teaching. African Journal of Research in Mathematics, Science and Technology Education, 15(3), 68-83.

Ferreira, J. G. (2004). An exploratory survey of male and female learner opinions on secondary school biology education in Gauteng. South African Journal of Education, 24(2), 105-107.

Furberg, A., \& Arnseth, H.C. (2009). Reconsidering conceptual change from a socio-cultural perspective: Analysing students' meaning making in genetics in collaborative activities. Cultural Studies of Science Education, 4, 157-191.

Gall, M., Gall, J. P., \& Borg, W. R. (2007). Educational research: An introduction (8th ed.). Boston, MA: Pearson.

Gilbert, J. K. (2006). On the nature of 'context' in Chemical Education. International Journal of Science Education, 28(9), 957-976.

Gilbert, J. K., Bulte, A. M. W., \& Pilot, B. (2011). Concept development and transfer in context-based science education. International Journal of Science Education, 33(6), 817-837.

Hung, W. (2006). The 3C3R Model: A conceptual framework for designing problems in PBL. The Interdisciplinary Journal of Problem-Based Learning, 1(1), 55-77.

Ibanez-Orcajo, M. T., \& Martinez-Aznar, M. M. (2005). Solving problems in genetics, Part II: Conceptual restructuring. International Journal of Science Education, 27(12), 1495-1519.

Jenkins, E. W., \& Nelson, N. W. (2005). Important but not for me: Learners' attitudes towards secondary school science in England. Research in Science \& Technological Education, 23(1), 41-57.

Knight, J. K., \& Smith, M. K. (2010). Different but equal? How non-majors and majors approach and learn genetics. CBE-Life Sciences Education, 9, 34-44.

Krajcik, J., McNeill, K. L., \& Reiser, B. (2008). Learning-goals-driven design model: Curriculum materials that align with national standards and incorporate project-based pedagogy. Science Education, 92(1), 1-32.

Lewis, J., \& Kattmann, U. (2004). Traits, genes, particles and information: Re-visiting learners' understanding of genetics. International Journal of Science Education, 26(2), 195-206.

Maloney, J. (2007). Children's roles and use of evidence in science: An analysis of decision-making in small groups. British Educational Research Journal, 33, 371-401.

Mji, A., \& Makgato, M. (2006). Factors associated with high school learners' poor performance: A spotlight on mathematics and physical science. South African Journal of Education, 26(2), 253-266.

O'Loughlin, M. (1992). Rethinking science education: Beyond Piagetian constructivism toward a socio-cultural model of teaching and learning. Journal of Research in Science Teaching, 29, 791-820.

Onwu, G. O. M., \& Kyle, W. C., Jr. (2011). Increasing the socio-cultural relevance of science education for sustainable development. African Journal of Research in Mathematics, Science and Technology Education, 15(3), $5-26$.

Onwu, G. O. M., \& Stoffels, N. (2005). Instructional functions in large, under-resourced science classes: Perspectives of South African teachers. Perspectives in Education, 23(3), 79-91.

Organisation for Economic Co-operation and Development [OECD]. (2004). Problem-solving for tomorrow's world: First measures of cross curricular competencies from PISA 2003. Paris: Global Science Forum (OECD).

Queensland Studies Authority. (2004). Chemistry: Extended trial pilot syllabus. Brisbane, Queensland: Queensland Studies Authority.

Reddy, V. (2006). The state of mathematics and science education: Schools are not equal. In S. Buhlungu (Ed.), State of the nation: South Africa, 2005-2006 (pp. 392-416). Pretoria: HSRC Press.

Roth, W. M., \& Lee, S. (2004). Science education as/for participation in the community. Science Education, 88 , 263-291.

Sadler, T. D. (2009). Situated learning in science education: Socio-scientific issues as contexts for practice. Studies in Science Education, 45, 1-42.

Schreiner, C., \& Sjøberg, S. (2004). Empowerment for action? How do young people relate to environmental challenges? In S. Alsop (Ed.), The affective dimension of cognition: Studies from education in the sciences (pp. 53-69). Dordrecht, the Netherlands: Kluwer.

Solomon, J. (1987). Social influences on the construction of pupils' understanding of science. Studies in Science Education, 14, 63-82.

Taasoobshirazi, G., \& Carr, M. (2008). A review and critique of context-based physics instruction and assessment. Educational Research Review, 3(2), 155-167.

Taylor, P., \& Mulhall, A. (1997). Contextualizing teaching and learning in primary schools: Using agricultural experience (Vol.1). London: Department of International Development.

Whitelegg, E., \& Parry, M. (1999). Real-life contexts for learning physics: Meanings, issues and practice. Physics Education, 34(2), 68-72. 
Wieringa, N., Janssen, F. J. J. M., \& Van Driel, J. H. (2011). Biology teachers designing context-based lessons for their classroom practice - the importance of rules-of-thumb. International Journal of Science Education, 33(17), 2437-2462.

Wilke, R. R. (2003). The effects of active learning on student characteristics in a human physiology course for nonmajors. Advances in Physiology Education, 27(4), 207-223. 